\title{
BATTERED WOMAN SYNDROME: PROSPECT OF SITUATING IT WITHIN CRIMINAL LAW IN INDIA
}

\author{
AISHWARYA DEB, \\ West Bengal National University of Juridical Sciences (Kolkata, India)
}

https://doi.org/10.21684/2412-2343-2021-8-4-103-135

In patriarchal cultures, like the one prevalent in India, rigid, polarised and hierarchical gender roles work to establish a strong normative relationship between gender and the treatment of offenders committing violent crimes such as homicide. While most of the common law countries have already undergone a social change towards making their criminal laws more gender-sensitive by accommodating the experiences of battered women, the situation in India is quite different. Indian courts have recognised Battered Woman Syndrome very recently in only three cases, much differently than courts in other jurisdictions. While in other countries, Battered Woman Syndrome has been adduced by the advocates of battered women to support defence pleas, Indian Courts have resorted to it only to explain the effects of a battering relationship. The fact that Battered Woman Syndrome has only been recognised in such a small number of cases and the lack of scholarship in this particular area clearly resonates the resistance of the Indian criminal law towards women's accounts of their experiences. Drawing on the example of the three cases, the author makes an attempt to put forth feminist legal arguments and offer a fresh perspective on the possibility of using Battered Woman Syndrome as a defence to address the concerns of battered women who end the cycle of violence by ending the lives of the abuser in a "kill or be killed" situation. Since Battered Woman Syndrome as a subject has been extensively researched in other common law countries, the present study limits itself to the Indian jurisdiction only. This paper also challenges the effectiveness of the existing defences under the Indian Penal Code, 1860 in accommodating the cases of battered women, and highlights the need for the introduction of a new justificatory defence as a plausible solution.

Keywords: Battered Woman Syndrome; criminal law; defence; gender; homicide; Indian Penal Code. 
Recommended citation: Aishwarya Deb, Battered Woman Syndrome: Prospect of Situating It Within Criminal Law in India, 8(4) BRICS Law Journal 103-135 (2021).

\section{Table of Contents}

\section{Introduction}

\section{India and its Battered Women}

\subsection{Background}

1.2. Battered Woman Syndrome in India

\subsection{Defending Battered Women in the Court of Law}

1.3.1. Provocation: A Substantive Defence?

1.3.2. Examining the Doctrine of Self-Defence

1.3.3. Insanity: Excusing a Battered Woman

\section{Limitations of Battered Woman Syndrome and the Need}

\section{for a New Defence}

\subsection{Battered Woman Syndrome: A Convenient Label} or a Real Syndrome?

\subsection{The Path Ahead: Need for a Complete Defence}

\section{Conclusion}

\section{Introduction}

Justice may be depicted as a woman, but, according to the dominant ideology, law is male, not female.'

The Battered Women's Movement (hereinafter "BWM") emerged in the United States during the 1970 s to focus upon the legal situation of battered women who killed their abusers to put an end to the violence within the four walls of the house. These women faced murder convictions because their cases did not fall within the scope of the traditional defences available to a homicide charge. In many cases, a clear picture emerged of the fact that abused women killed their abusers when they had no other alternatives and the violence had escalated to the point of "kill-or-be-killed."' However, because it was developed on the basis of male experiences, the traditional

Christine H. Farley, Confronting Expectations: Women in the Legal Academy, 8(2) Yale J.L. \& Feminism 333, 348 (1996) (quoting Frances Olsen, The Sex of Law in The Politics of Law 453, 454 (David Kairys ed., 1990)).

2 See R. Emerson Dobash \& Russell Dobash, Violence Against Wives: A Case Against Patriarchy 15 (1979) (laid the foundation for the proposition that the use of force against wives should be viewed as an attempt to exercise "coercive control" on the part of the husband to bring about a desired state of affairs, and the abused wives stayed back owing to lack of economic and personal support). 
structures of provocation and self-defence doctrines failed to recognise gendered fear and were not concerned with the domestic zone of homicide. ${ }^{3}$ The very objective structure of the defences as well as the elements of law, excluded the relevance of women's experiences. As a result, one question that frequently arose during the trials faced by such women was, "Why doesn't she leave the relationship?" For the woman being on the receiving end of torture and violence, moving out of an abusive relationship was an option resulting in the complete absence of any psychological and physical support structure for women in such scenario. ${ }^{4}$ It was only in the late 1970s that an American clinical psychologist named Lenore Walker introduced the concept of Battered Woman Syndrome (hereinafter "BWS") to answer the aforesaid question and recognise the severity of intimate partner violence that takes place within the four walls of a household. The term BWS was coined to describe a sociological theory of behavioural patterns based upon the physical and psychological abuse found in women involved in abusive relationships. Walker defined a "battered woman" as:

a woman who is repeatedly subjected to any forceful physical or psychological behaviour by a man in order to coerce her to do something he wants her to do without any concern for her rights. Battered women include wives or women in any form of intimate relationships with men. Furthermore, in order to be classified as a battered woman, the couple must go through the battering cycle at least twice. ${ }^{5}$

Through her work, Walker countered the idea of "female masochism," stating that people frequently label battered women as masochistic for not leaving the relationship without considering the woman's inability to help herself. ${ }^{6}$ For the very first time, violence was recognised outside of the confines of marriage. Walker attributed a battered woman's behaviour to the theories of "learned helplessness" and the "cycle theory of violence." The creation of BWS not only drew public attention to the problem of violence against women, but it also gradually entered the legal arena to support the defence claims of women facing homicide charges.

BWS found recognition in jurisdictions such as the United States and Canada in 1990, and the United Kingdom and Australia (in Queensland) in 1991 where it has been admitted through expert testimony to substantiate a defence plea and justify the reasonableness of a battered woman's actions. Subsequently, these countries reformed their respective criminal laws and gave effect to BWS in three ways to accommodate the

3 See Lenore E. Walker, Terrifying Love: Why Battered Women Kill and How Society Responds 49-53 (1989).

4 Lenore E. Walker, The Battered Woman Syndrome 86 ( $4^{\text {th }}$ ed., Springer, 2016).

5 Lenore E. Walker, The Battered Woman 16 (1979).

6 Id. at ix.

7 Walker 2016, at 50. 
circumstances of battered women either by (a) modifying the traditional defences, ${ }^{8}$ or (b) creating a new defence, ${ }^{9}$ or (c) expanding the scope of expert testimony. ${ }^{10}$ Although BWS came as an answer to a simple question raised in trials, it successfully elevated social recognition of the reality of domestic violence and highlighted the need for ungendering criminal law, despite giving rise to the stereotype of battered women as weak, helpless victims. While the aforementioned countries have already undergone a social change towards making their criminal laws more gender-sensitive by accommodating the experiences of battered women, the situation in India is quite different. Despite the fact that domestic violence has been extensively researched in India over the last thirty years, intimate partner violence has only been recognised civilly under the Protection of Women against Domestic Violence Act, 2005 and recognition of battered women's circumstances remains perplexingly under theorised within criminal law in India. Indian courts have very recently recognised BWS in only three cases," much differently than courts of other jurisdictions. While in other countries BWS has been adduced by the advocates of battered women to support defence pleas, Indian courts have resorted to BWS only to explain the effects of a battering relationship. The fact that BWS has only been recognised in a small number of cases proves the resistance of the Indian criminal law towards women's accounts of experiences. Even before the recognition of BWS in India, Ved Kumari had highlighted the fact that the defences under the Indian Penal Code, 1860 (hereinafter "IPC") do not accommodate the circumstances faced by a battered woman. ${ }^{12}$ According to a study carried out by Jean Dreze, murders by women are extremely rare and usually occur in response to extreme circumstances like

8 See Paul H. Robinson, Abnormal Mental State Mitigations of Murder: The US Perspective in Loss of Control and Diminished Responsibility: Domestic, Comparative and International Perspective 292 (Alan Reed \& Michael Bohlander eds., 2011); Aya Gruber, A Provocative Defense, 103(2) Calif. L. Rev. 273 (2015); see also Alan Norrie, The Coroner's and Justice Act 2009 - Partial Defences to Murder (1) Loss of Control, 4 Crim. L. Rev. 275 (2010) (discussing the newly introduced $\S 54$ and $\S 55$ of the Coroner's and Justice Act, 2009 as a partial defence to homicide).

9 See Amanda Clough, Battered Women: Loss of Control and Lost Opportunities, 3(2) J. Int'I \& Comp. L. 279, 316 (2016); Susan S.M. Edwards, Anger and Fear as Justifiable Preludes for Loss of Self-Control, 74(3) J. Crim. L. 223 (2010).

10 See Elizabeth Sheehy et al., Defences to Homicide for Battered Women: A Comparative Analysis of Laws in Australia, Canada and New Zealand, 34(3) Sydney L. Rev. 467, 468 (2012); Department of Justice Canada, Report on Sentencing for Manslaughter Cases Involving Intimate Relationships (2003) (May 18, 2021), available at http://www.justice.gc.ca/eng/rp-pr/other-autre/smir-phiri/bg-cont.html; Anthony Hopkins \& Patricia Easteal, Walking in Her Shoes: Battered Women Who Kill in Victoria, Western Australia and Queensland, 35(3) Alt. L.J. 132 (2010); New Zealand Law Commission, Understanding Family Violence: Reforming the Criminal Law Relating to Homicide, NZLC R139 (2016) (May 18, 2021), available at https://www.lawcom. govt.nz/sites/default/files/projectAvailableFormats/R139\%20Understanding\%20Family\%20Violence\%20 -\%20Reforming\%20the\%20Criminal\%20Law\%20Relating\%20to\%20Homicide.pdf.

11 Manju Lakra v. State of Assam, (2013) S.C.C. OnLine Gau. 207; Amutha v. State, 2014 (2) M.W.N. (Cr.) 605; State v. Hari Prashad, (2016) 228 D.L.T. 1 (D.B.).

12 Ved Kumari, Gender Analysis of Indian Penal Code in Engendering Law: Essays in Honour of Lotika Sarkar 139 (Amita Dhanda \& Archana Parashar eds., 1999). 
harassment or infidelity, with the vast majority of the cases going unreported..$^{13}$ This persistently low ratio of women committing murder demonstrates that existing criminal law has developed solely on male experience. In such a scenario, when women face trial for murder, their actions are judged on the basis of this male experience and women are required to fit their psychological traits within the conventional considerations that are pertinent to men and inevitably, when a woman fails to satisfy such considerations, they are termed as offenders.

Indian courts have only used BWS as a theory to explain the consequences of battering rather than as a defence or in support of a defence plea. However, this recognition of BWS solely through judicial discretion leaves open the possibility of conviction for women who kill their abusers. The existing literature on this subject, with reference to the Indian context, has put forth a clear argument for the inclusion of BWS defence to address the concerns of these women without taking into account the inherent limitations of the theory of BWS. However, the actual necessity lies in the reform of the existing criminal law to accommodate the cases of battered women, as well as for women's experiences to be integrated into the criminal justice system. This research paper enriches the existing scholarship relating to BWS in India by bringing together different perspectives and exploring the possibility of situating BWS within criminal law in India to cut into the male-centric structure by addressing the concerns of battered women. The paper offers a critique of the existing defences under the IPC and the discussion also advocates for introducing a new justificatory defence to accommodate the cases of battered women.

\section{India and its Battered Women}

\subsection{Background}

Under the influence of the BWM in the United States, the feminist movement in India, also known as the Anti-dowry Violence Movement (hereinafter "ADVM"), began in the early 1970s. Prior to the 1970s, domestic violence in India was an issue which was treated with benevolent neglect. Violence within the four walls of a house was considered a family problem and even the legal authorities surmised that the situation would be best handled if it remained inside the confines of the house. Moreover, obtaining legal redress for victims of domestic violence posed a significant challenge for women, as the existing laws at that point of time were inadequate to protect against the many forms of violence against women. It was only in the 1980s that the IPC was amended to penalise acts of extreme cruelty to women that are likely to drive a woman to commit suicide or cause grave injury under Section 498A, as well as acts of cruelty in response to dowry demands under Section 304B. However, much like the

13 Jean Dreze \& Reetika Khera, Crime, Gender, and Society in India: Insights from Homicide Data, 26(2) Popul. Dev. 335 (2000). See P.M.K. Mili \& Neethu S. Cherian, Female Criminality in India: Prevalence, Causes and Preventive Measures, 10(1) Int'l J. Crim. Just. Sci. 65 (2015). 
early feminist work in BWM, the ADVM only addressed the problem of wife abuse for dowry demands, ascertaining the fact that abuse took place only within marriage. Due to these limited characterizations, perpetrators of domestic violence unrelated to dowry demands escaped prosecution, contributing to a pervasive societal attitude that is tolerant of other forms of violence against women. The second-wave of the feminist movement in India saw a deviation from the agenda of ADVM and, after much hue and cry over the issue of domestic violence and the awareness campaigns organised by various women's rights groups, ${ }^{14}$ the instrumentalities of the State began to recognise the need for laws in order to protect women from all forms of domestic abuse and provide some sort of relief. This led to the creation and enforcement of a new statute, the Protection of Women from Domestic Violence Act, 2005, specifically designed to protect women from abuse within their homes, regardless of their marital status. The changes under this legislation were mainly directed towards improving the responses by legal authorities to domestic violence, the procedure for filing complaints and subsequent prosecution and finally, making attempts to educate the public about the seriousness of the issue, as well as also providing assistance to battered women. Despite the fact that "Cruelty by husband or his relatives" is the most reported crime against women in various States, accounting for 33.2 percent of all crimes in India, ${ }^{15}$ the conviction rate is only 15.9 percent. ${ }^{16}$ The general attitude seems to be that the sanctity of the family life pervades the world of law enforcement. As a result, the arrest of the offender is generally seen as a last resort in domestic violence issues. It is only in extreme circumstances that a woman might think about ending the violence faced at the hands of her abusive partner.

\subsection{Battered Woman Syndrome in India}

Unlike other countries, India only recently recognised BWS, and thus there has been limited research on the admissibility of BWS in India. However, the Madras High Court in 1989 had developed the concept of "Nallathangal's Syndrome," which is often considered as the precursor of BWS in India, in Suyambukkani v. State of Tamil Nadu. ${ }^{7}$ In this particular case, the accused had been living since her marriage in a state of constant adversity, and had also faced abuse by her callous husband. When the situation became unbearable, she decided to commit suicide along with her children,

14 With the rising number of reported abuse without any effective legislation for non-dowry abuses, the Lawyer's Collective began working on a draft of model domestic violence legislation in 1992. See Indira Jaising, Domestic Violence and the Law, 1 J. Nat'I Hum. Rts. Comm'n 72, 73 (2002).

15 National Crime Records Bureau, Ministry of Home Affairs, Crime in India - 2017 (May 18, 2021), available at https://ncrb.gov.in/en/crime-india-2017-0. See also Decoding NCRB Report, The Hindu, 23 October 2019 (Oct. 23, 2019), available at https://www.thehindu.com/news/national/decodingncrb-report/article29775632.ece.

16 Crime in India - 2017, supra note 15.

171989 L.W. (Cri.) 86. 
by going to the nearest well. But she survived, and her children died as a result, for which she was accused of murder. The court introduced the concept of Nallathangal's Syndrome by referring to an old Tamil literature named "Nallathangal Ballad" which narrated the tribulations of a rich woman who was reduced to unbearable misery and committed suicide along with her children. ${ }^{18}$ The court held that the syndrome could be considered one of the exceptions under Section 300 of the IPC, and she was held guilty of culpable homicide not amounting to murder. However, the first research on BWS, undertaken in 2010, did not speak about the existence of Nallathangal's Syndrome and only highlighted that battered women in India did not have recourse to any legal defences available under the IPC. ${ }^{19}$

Subsequently, in 2013, the Gauhati High Court in Manju Lakra v. State of Assam ${ }^{20}$ recognised BWS for the very first time in India. The accused, who like every other Indian wife in similar cases, suffered from unprovoked acts of violence, had on one such occasion killed her abusive husband. The incident occurred on a day when her husband came home in a drunken state and started beating his wife with a piece of wood as a result of which she sustained injuries to her head and eyes. ${ }^{21}$ Unable to bear the violence at the hands of her husband any longer, she snatched the piece of wood and hit him back on his legs, head, neck, chest and abdominal area, as a result of which he succumbed to death. The trial court had held her guilty of murder and she had preferred an appeal to the High Court. The High Court accepted the fact that the circumstances prevailing in the family of the accused amounted to domestic violence as described under the Protection of Women from Domestic Violence Act, 2005.2. Unlike in cases in other countries, the accused had not adduced expert evidence on BWS, but it was the court itself that referred to BWS while considering the fact that while it may appear that the husband is the victim and the aggressor is the wife, in reality the wife may be the actual victim. ${ }^{23}$ While deliberating upon the issue as to whether the act of the accused fell within the scope of culpable homicide not amounting to murder, the High Court referred to $R v$. Ahluwalia ${ }^{24}$ and highlighted the admissibility of BWS in other jurisdictions such as the United States, Australia and Canada to help explain the reasonableness of a woman's actions against her abuser. ${ }^{25}$ The High Court also compared the immediacy requirement under Section 304B of the IPC which leads

181989 L.W. (Cri.) 86, 121.

19 Paramita Nandy, Battered Woman Syndrome, SSRN (2010) (May 18, 2021), available at https://ssrn. com/abstract $=1689521$.

20 (2013) S.C.C. OnLine Gau. 207.

21 Id. १3(ii).

22 Id. $₫ 67$.

23 Id. 999.

24 [1992] 4 All E.R. 889.

25 (2013) S.C.C. OnLine Gau. 207, $\$ 100$. 
to the unnatural death of a woman to the act committed by the accused in this case, reaching the conclusion that if circumstances potential enough to distinguish the suicide of a woman have been recognised, the same set of circumstances should be equally recognised to be potential enough to turn such women into an aggressor so much so that she ends the life of her abuser. ${ }^{26}$ While explaining the sequence of events that led to the act of aggression, the High Court stated that:

Though she had been controlling and suppressing the rage and the resentment, which had been building up inside her, her rage and resentment were waiting to erupt at any further violent conduct of her husband. The accused-appellant had been, thus, sitting on a volcano of resentment and rage, which had been continuously building up and boiling inside, waiting to burst open and even a small flicker of any further intolerable behaviour of her husband could have made the volcano erupt and that is precisely what happened on the fateful evening, when her husband, having come home in drunken state, as usually he did, started beating her up. The provocation, which the conduct of the accused-appellant's husband so provided to the accusedappellant, was not only grave, but can be perceived as sudden, too. ${ }^{27}$

In light of this, the High Court held that her case would fall well within the First Exception of Section 300 and therefore reduced her sentence.

As a result, BWS came to be recognised in cases other than homicide of abusers by women. In Amutha v. State ${ }^{28}$, the Madras High Court granted anticipatory bail to a woman, a victim of domestic violence at the hands of her husband, who had pushed her daughters into the well and also jumped into the well herself but survived. The Honourable Court, recognising BWS as accepted in $R$ v. Ahluwalia, ${ }^{29}$ held that the continuous provocative conduct of the husband for years and the triggering action on the night of the incident caused her to lose self-control and take the decision to kill herself and her daughters in order to put an end to the violence. The High Court also made reference to Nallathangal's Syndrome conceptualised in Suyambukkani because the facts in the present case were very similar to those in that case. Apart from these cases, very recently the Delhi High Court in State v. Hari Prashad $^{30}$ convicted the accused husband for aiding and abetting the suicide of his wife, Pushpa, and held that the provocation by the husband became her compulsion to end the domestic relationship by taking her own life. According to the facts of the

26 (2013) S.C.C. OnLine Gau. 207, १109.

27 Id. $१ 116$.

282014 (2) M.W.N. (Cr.) 605.

29 [1992] 4 All E.R. 889.

30 (2016) 228 D.L.T. 1 (D.B.). 
case, the accused was dissatisfied with the dowry and used to physically and mentally torture Pushpa. In order to save herself from never-ending violence, she lodged a complaint with the Crime against Women Cell where the accused apologized for his behaviour and promised in writing that he would not consume alcohol or beat her. Nonetheless, on the night Pushpa committed suicide she was brutally beaten by the accused. Even though the trial court had acquitted him, the High Court recognised the concept of BWS while explaining the effect of the battering relationship on the wife by highlighting the fact that the battering episodes kept her in constant fear of harm. The High Court also noted how Pushpa's actions differed from those of other women who kill their abusers to put an end to the violence, which is supported by the BWS evidence, because she was biologically weaker. The High Court finally held the accused guilty under Section 306 of the IPC.

From the foregoing analysis of the cases, a few conclusions may be drawn. To begin with, BWS has only been recognised by the courts as a theory to rely on and explain the effects of battering relationships, as there was no precedent for allowing expert testimony on BWS in any of the cases. Thus, the recognition of BWS only through judicial discretion leaves open the possibility of conviction for women who kill their abusers in such circumstances. Furthermore, because there have been only three cases where BWS has been recognised thus far, the courts have been forced to refer to an international precedent to accommodate the case of a battered woman within the defences claimed. Secondly, the judiciary has used BWS to explain the effects of a battering relationship even in cases where a woman harms herself or someone else other than the abuser. The concept of BWS has also been utilised to establish the guilt of the accused, as in Hari Prashad. Thirdly, all of the cases reveal a fundamental issue that only when a woman can no longer find help, or when legal institutions also fail to provide any sort of protection to battered women, do they take such extreme steps.

As a result of the recognition of BWS by the Indian courts, various scholars have started mooting for the inclusion of BWS within the general legal defences. While some have argued in favour of the inclusion of a battered woman's psychological conditions in cases of homicide, ${ }^{31}$ others have argued for accommodating the cases of battered women by expanding the structure of the traditional defences. For instance, an argument for incorporating psychological self-defence in the IPC has been put forth by Shreyas Gupta in his work. ${ }^{32}$ In order to support his argument, Gupta refers to $R v$. Ahluwalia where the psychological effects of living in a battering relationship were taken into account. Gupta also made an attempt to refer to the expansion of self-defence structures in countries such as Canada, Australia, and others. ${ }^{33}$ However, his analysis failed to consider the consequences of the inclusion of such a defence

31 Shalu Nigam, Battered Women Syndrome: Applying this Legal Doctrine in the Indian Context, SSRN (2016) (May 18, 2021), available at https://ssrn.com/abstract=2819322.

32 Shreyas Gupta, Right to Kill: The Case of the Battered Women, 3(2) Nirma Univ. L.J 59 (2014).

${ }^{33}$ Id. at 65 . 
within the criminal justice system in India as he did not consider the applicability of other defences in cases involving battered women. On the other hand, there is also an argument for the inclusion of the cases of women suffering from BWS by citing the Coroners and Justice Act, 2009 of the United Kingdom. ${ }^{34}$ There have been suggestions for amending Sections 300 and 100 of the IPC to modify the requirement of suddenness and immediacy in order to make the defences more suitable for battered women. ${ }^{35}$ While the former argument paves the way for a new defence which would result in the acquittal of battered women, the latter puts forth suggestions to make a case for mitigating the liability unjustly imposed by the IPC on battered defendants, who kill their husbands by allowing expert testimony on BWS. These conflicting proposals have made it pertinent to delve into the issue of battered women's defences, the defences which are raised when battered women who have been abused for months and have suffered horrific experiences, strike back and kill their batterers.

\subsection{Defending Battered Women in the Court of Law}

For a violated woman who is on trial for killing her partner with whom she was involved in a battering relationship, there are several defence tactics which advocates have argued and feminist scholars have advocated that can be used to partially or completely exculpate the woman in other jurisdictions. In India, women accused of homicide have typically pleaded the partial defence of provocation, the complete justification theory of self-defence or a plea of insanity. ${ }^{36}$ The discussion here, in particular, outlines the efficacy of possible defences to a homicide charge and their utility in defending battered women who kill their abusers.

\subsubsection{Provocation: A Substantive Defence?}

The law governing homicides mainly revolves around the idea that the perpetrator was morally culpable and intended to kill the victim. The law attaches the highest level of culpability when such a person acts with premeditation and deliberation. However, the problem arises when such a law is employed to convict a woman for murder. It is a well-known fact that a woman's social reality varies, to a large extent, from that of a man's owing to cultural constructs. Because the law has traditionally been created by and for men, it fails to take into account the differences between the two biologically and socially distinct individuals when applying the legal theories. The problem is even worse for battered women who kill in order to protect themselves or their dependants from further instances of violence, as they are faced with criminal implications which are not designed to accommodate women's behaviour and responses. As a result, they suffer the consequences of murder convictions. However,

34 Aman D. Borthakur, The Case for Inclusion of Battered Woman Defence in Indian Law, 11(1) NUJS L. Rev. 1 (2018).

35 Id. at 18.

36 Dreze \& Khera 2000, at 337. 
Indian courts have accommodated the cases of battered women only within the realm of partial defence of provocation. In such a scenario, it becomes pertinent to examine whether the defence of provocation pleaded by battered women takes into consideration their gender-specific circumstances.

The provocation doctrine owes its development to common law judges who frequently invoked it to mitigate the severity of the death penalty in cases of homicide. ${ }^{37}$ Even though times have changed, the fact that provocation is still recognised as a partial defence to a murder charge indicates an empathy for "heat of passion" killings. According to the IPC, provocation in the case of murder is much more than an extenuating circumstance as it takes away homicide from the category of murder and thereby, changes the very nature of the offence. Despite its importance, the law regarding provocation remains in a state of "bewildering uncertainty." ${ }^{\prime \prime 38}$ The major reason behind this is the acceptance of the objective yardstick, namely, the "reasonable man standard" in order to assess the seriousness of the provocation when pleaded as a defence to a charge of murder. The phraseology, imported from the English courts, has created more confusion rather than providing an easier way of interpreting the entire provocation argument. The reasonable man standard has been consistently used to ascertain the degree of provocation required to succeed in a claim of such defence. According to the terminology of Exception 1 to Section 300 of the IPC, "if the offender whilst deprived of the power of self-control by grave and sudden provocation, causes death ...," it is clear that only "grave and sudden provocation" can mitigate the offence of murder. However, even before the emergence of the "reasonable man" standard, the paradigm of provocation evolved in India within the realm of domestic homicides, particularly murders motivated by jealousy and rage. The evolution can be traced back to 1901, when in Abalu Das v. Empress,,$^{39}$ the accused found a man entering his house at night at the invitation of his wife, with whom he had sour relations and being enraged by such an act, he caught hold of the deceased and took him outside the house to some distance and assaulted him so severely that he subsequently died of the injuries received. ${ }^{40}$ The Calcutta High Court held that the circumstances under which the deceased was found in the house of the accused on the night of the crime were sufficient to cause grave and sudden provocation to the accused. ${ }^{41}$ The High Court also held that the provocation was of such a nature that it would continue to influence the feelings of the accused for a considerable period of time even after the deceased was discovered in the house

37 Joshua Dressler, Rethinking Heat of Passion: A Defense In Search of a Rationale, 73(2) J. Crim. L. \& Criminol. 421 (1982).

38 Id. at 328 .

39 (1901) S.C.C. OnLine Cal. 69.

40 Id. $१ 1$.

41 Id. 95. 
with the accused's wife. ${ }^{42}$ Many cases followed, but the most important one was K.M. Nanavati v. State of Maharashtra, ${ }^{43}$ where the accused pleaded the defence of provocation. In this case, the wife of the accused confessed to him that she had had illicit relations with the deceased. On hearing this, the accused began to consider asking the deceased for an explanation. But after a few hours, he bought a revolver, did some official work, and then went up to the deceased and shot him dead. Since three hours had elapsed between the time the accused heard the news and the time the murder took place, the High Court held that the murder was premeditated and that the accused could not claim the defence of provocation. Despite the fact that the accused could not get the benefit of the defence, the decision went on to establish the law on provocation. Subsequently, in Chinnan v. State ${ }^{44}$ where the accused killed the deceased after a quarrel with the deceased over an illicit relationship between the wife of the accused and the deceased, the High Court accepted the accused's plea of provocation and held him guilty of culpable homicide not amounting to murder. ${ }^{45}$ In another similar case, V. Dharmalingam v. State, ${ }^{46}$ the accused and the deceased, his wife, had a strained relationship because he suspected her of infidelity. Despite several warnings, the deceased continued with her illicit relationship and on the night of the incident, she had also threatened the accused, as a result of which he attacked her. The High Court held that the accused was entitled to the benefit of the exception "grave and sudden provocation" and held him guilty of culpable homicide not amounting to murder. ${ }^{47}$ These cases give a flavour of the apparent acceptability of being provoked by jealousy or anger whereby men have been able to exact unusual or fatal sanctions on their wives or their paramours. Thus, the provocation defence appears to be plagued by significant gender issues as a result of its origins.

Coming back to the reasonableness standard, it was in K.M. Nanavati v. State of Maharashtra, ${ }^{48}$ whereby the Supreme Court opined that the test of "grave and sudden provocation"is,

Whether a reasonable man belonging to the same class of the society as the accused, placed in the situation in which the accused was placed would be so provoked as to lose his self-control..$^{49}$

\footnotetext{
42 (1901) S.C.C. OnLine Cal. 69, 16.

$43 \quad$ A.I.R. 1962 S.C. 605.

44 (1995) S.C.C. OnLine Mad. 314.

45 Id. $\uparrow 13$.

46 (2008) S.C.C. OnLine Mad. 359.

47 Id. $१ 10-\uparrow 16$.

48 A.I.R. 1962 S.C. 605.

49 Id. 985 (K. Subba Rao, J., majority opinion).
} 
The Supreme Court was also of the view that what a reasonable man would do in the face of provocation depends upon

the custom, manners, way of life, traditional values, etc., i.e., in short, the cultural, social and emotional background of the class of society to which an accused belongs. $^{50}$

What is pertinent to note here is that the objective test has an inherent vagueness and uncertainty. In this relation, it would be relevant to quote the opinion of the Supreme Court in Budhi Singh v. State of H.P., ${ }^{51}$ where it was held that,

The doctrine of grave and sudden provocation is incapable of rigid construction leading to any principle of universal application. ${ }^{52}$

Subsequently, the Supreme Court went on to say that,

An offence resulting from grave and sudden provocation would normally mean that a person placed in such circumstances could lose self-control but only temporarily and that too in proximity to the time of provocation..$^{53}$

The Supreme Court also relied upon the reasonable man standard in order to conclude that the offence was not culpable homicide amounting to murder.

However, generalising the experiences of the person pleading a defence of provocation with a "reasonable man" is simply abstracting such individuals out of their social reality, thereby conferring on them a formal equality. But this formal equality is merely illusory, since the defendant and the hypothetical "reasonable man" are not in reality equal, which might ultimately lead to unjust consequences. Even though the term 'man' is considered the genderless norm upon which all other forms of identity must rely, the legal system is inherently male and overtly seeks to empower the male norm. Consequently, women experience discrimination in subtle ways through male-centric power dominance, which expects the women to assimilate into the male standard rather than allowing them to maintain a separate position for themselves. In the same way, the defence of provocation is also steeped in masculinity and envisaged mainly in terms of male consciousness notwithstanding the fact that women, especially battered women, do not react to provocation in any typical male-designated way. If this standard is applied in cases involving

\footnotetext{
50 A.I.R. 1962 S.C. 605, १84.

51 (2012) 13 S.C.C. 663.

52 Id. $\uparrow 18$ (S. Kumar, J., majority opinion).

53 Id.
} 
battered women who kill, it would create a double injustice by filtering out the social conditions which may have contributed to the battered woman's act of violence.

The Gauhati High Court in Tilok Rajawar v. State of Assam ${ }^{54}$ had to determine whether the adequacy of provocation should be measured from the point of view of an "ordinary reasonable man" or that of the alleged offender, taking into account his idiosyncrasies. The High Court was of the opinion that the reasonableness of the offender's action should be determined from the view point of a person in the offender's situation. This requirement makes it inherently difficult for battered women to prove the reasonableness of their action in killing their abuser. Because the woman does not fit the stereotypical norm, irrespective of what evidence has been adduced in her favour, her conduct will be judged against the reasonable man standard without considering the fact that a battered woman's perception of danger might differ from those of men.

Another major difficulty that the defence of provocation poses in front of the battered woman is the test of "proximity" or the requirement of immediacy. In Sukhlal Sarkar v. Union of India, ${ }^{55}$ the Supreme Court held that a person claiming the benefit of Section 300 Exception 1 should demonstrate that the provocation was grave and sudden enough to deprive him of self-control and that he caused the death of such person while he was still in that state of mind. The term "grave" implies that the provocation is of such nature that it causes apprehension in the defendant and "sudden" implies an action must be instant and unexpected so far as to provoke the defendant. ${ }^{56}$ This requirement demands that the accused react immediately after the provoking incident. Any delay between the provocation and the response, is thus interpreted as a contradiction to the loss of self-control which forms the essence of the defence plea. Because of the limitations of the immediacy requirement, which focuses on the most recent act of provocation, the law has struggled to find provocative behaviour that could justify a killing. For instance, in Gyanendra Kumar $v$. State of U.P, ${ }_{1}^{57}$ where the accused had killed the deceased after quarrelling with him, the Supreme Court upheld his conviction for murder and opined that where there is sufficient time for cooling off, there is no sudden provocation and the act of the accused is deliberate. ${ }^{58}$ The standard was further elaborated in B.D. Khunte v. Union of India ${ }^{59}$ where the accused had been physically assaulted by his superior, the deceased, who was forcing him to engage in unnatural carnal intercourse in order

54 (1986) S.C.C. OnLine Gau. 113.

55 (2012) 5 S.C.C. 703

56 Id. $१ 9-१ 10$.

57 A.I.R. 1972 S.C. 502.

58 Id. १9 (followed in Bati Kunjami v. State, 1996 Cr.L.J. 1431 (Ori.); State of Karnataka v. Surendra, 1995 Cr.L.J. 3824 (Kant.)).

$59 \quad$ (2015) 1 S.C.C. 286. 
to satisfy his lust. However, there was a significant time lapse before the accused committed the murder and there was no evidence that the provocation continued. In light of this, the Supreme Court held that this case did not fall under Exception I of Section 3000 , because the provocation had to be both grave and sudden in order for the defence to be successful. ${ }^{60}$ In Gnanagunaseeli v. State, ${ }^{61}$ where a woman, who was subjected to repeated insults by her husband, murdered him after discovering an illicit relationship with another woman in their matrimonial abode, the Madras High Court, having accepted the plea of partial defence of "grave" and "sudden" provocation, reduced her offence to culpable homicide not amounting to murder. Thus, it is quite evident that the courts have placed a high value on the requirement of proximity. On the contrary, in the case of battered women, the very nature of the prolonged violence, the apparent initial tolerance by the victim and her failure to respond immediately is contrary to this "heat of the moment" requirement of the elements of provocation. Such delay in reacting to the violence denotes revenge and the law does not recognise revenge per se.

However, a change was introduced by the courts with the recognition of the concept of "sustained provocation." In Suyambukkani, the High Court which introduced the concept of Nallathangal's Syndrome also conceptualised "sustained provocation" as a judicial creation envisaged by the architects of the IPC. ${ }^{62}$ The High Court went on to say that there is a fundamental difference between grave and sudden provocation and sustained provocation because the latter involves a series of more or less grave acts spread out over a period of time, the last of which "acting as the last straw breaking the camel's back may even be a very trifling one." ${ }^{\prime 63}$ The High Court also examined the possibility of including the syndrome as an exception under Section 300 of the IPC. The High Court held that since on the day of the incident the accused woman was beaten and assaulted by her husband, she decided to take the Nallathangal way, and therefore her act did not fall within the definition of murder as contemplated by the IPC. However, the High Court found her guilty of the offence under Sections 309 and 304 Part I and sentenced her appropriately. Also, in Vanarani v. State ${ }^{64}$ the Madras High Court again followed the same reasoning as in the aforementioned case where the accused woman had caused the death of her children and also attempted to commit suicide after facing homicidal violence. ${ }^{65}$ The same pattern was followed in Poovammal v. State $e^{66}$ where a grieving mother killed

60 (2015) 1 S.C.C. 286, ๆ14-१19.

611995 (II) C.T.C. 610.

621989 L.W. (Cri.) 86.

63 Id. $\$ 21$ (David Annoussamy, J., majority opinion).

64 (2001) I.C.T.C. $656,661$.

65 Id. $१ 1 \& \uparrow 12$.

66 (2012) 2 M.W.N. (Cri.) 276. 
her own son out of frustration and also attempted suicide. It would be pertinent to reproduce an extract from the judgment to understand the decision taken by the Madras High Court:

There may be incidents/occurrences, which are such that they may not make the offender suddenly make his outburst by his overt act. However, it may be lingering in his mind for quite some time, torment continuously and at one point of time erupt, make him lose his self-control, make his mind to go astray, the mind may not be under his control/command and results in the offender committing the offence. The sustained provocation/frustration nurtured in the mind of the accused reached the end of breaking point, under that accused causes the murder of the deceased. ${ }^{67}$

The Madras High Court held her guilty of culpable homicide not amounting to murder and reduced the sentence imposed by the Trial Court. However, these judgments failed to offer a principled justification for the addition of sustained provocation to the statutory list of exceptions.The decision of the Gauhati High Court in Manju Lakra ${ }^{68}$ wherein the High Court recognised BWS and broadened the scope of provocation as a defence for battered women who kill their abusers, came as a relief to battered women who kill their abusers. The question was whether the grave and sudden provocation should occur immediately preceding the murder or whether the time lag could be extended to a date far in advance of the date of murder. In this case, the accused woman suffered unprovoked acts of domestic violence, but on one occasion, the violence backfired and devoured the abusive husband. The High Court relied on the decision in Rv. Ahluwalia, which highlighted the concept of "cumulative provocation," and observed that:

Where the circumstances immediately preceding the fatal strike, may not be independent of the previous acts, treated so provocative as to make a man lose his power of self-control yet when the series of provocative circumstances preceding the fatal strike, were sufficient to deprive an ordinary man of his power of self-control, it may not be a proper appreciation of plea of provocation if the immediate provocative conduct preceding the cause of death, is taken into account excluding the previous series of acts, which were inextricably connected with the ultimate act of provocation leading to the cause of death. ${ }^{69}$

Thus, as per the opinion of the High Court, the series of acts that constitute "grave" and "sudden" provocation should be such which never really permitted the

67 (2012) 2 M.W.N. (Cri.) 276, १30 (P. Devadass, J., majority opinion).

68 (2013) S.C.C. OnLine Gau. 207.

69 Id. 987 (I.A. Ansari, J., majority opinion). 
defendant to calm down and act (namely, an absence of a cooling off period) and the act immediately preceding the killing of the abuser was the culmination of the previous provocative acts.

What can be inferred from the foregoing analysis is that Indian courts have, in particular circumstances, broadened the scope of partial defence of provocation to accommodate cases of women facing domestic violence and committing homicide as a result of it. However, since the expansion of such defences is a matter of judicial discretion, women face the risk of being convicted of murder. The defence of provocation is not a viable option for battered women who kill, primarily because it is not a justification defence, but rather an excuse which merely reduces the charge of murder to a lighter offence, thereby imposing culpability on the battered woman. It focuses only on the actor by comparing her to an ordinary reasonable man instead of focusing on the act itself, with regard to the circumstances which would justify it. A battered woman does not require an exemption from criminal liability; in fact, she should not be subject to criminal liability at all. Furthermore, considering the way in which the law of provocation has evolved, male defendants benefit in the sense that their offence is mitigated even if it is the result of jealousy or anger, while women defendants are denied a better disposition. This parallel use of the provocation defence for both killings motivated by jealousy and rage and killings out of violence faced at the hands of an abuser is unfair. After all, different reasons for killing should merit different legal responses.

\subsubsection{Examining the Doctrine of Self-Defence}

Even though Indian courts have not yet accommodated the cases of battered women within the realm of self-defence, many scholars, as discussed in the previous chapter, have mooted for the expansion of the self-defence structure. In such a scenario, it will be pertinent to examine the possibility of extending the right of private defence to battered women who commit homicide as against the partial defence of provocation. In India, criminal law authorises a person who is under a reasonable apprehension that his life is in danger to inflict death upon the aggressor, provided the harm inflicted is not greater than what is actually necessary for the purpose of self-defence. This is based upon the basic norm of self-preservation, which has been duly recognised by the criminal legislations of the majority of countries. ${ }^{70}$ Unlike the defence of provocation, self-defence is categorised as a justification defence as it exempts a person completely from criminal liability. When pleaded in case of a homicide charge, if the offence succeeds in satisfying the elements of the defence, there will be complete vindication rather than mere mitigation of a lessercrime. While explaining the genesis of the self-defence doctrine in India, the Supreme Court in Surjit Singh v. State of Punjab ${ }^{71}$ observed that,

70 Ratanlal \& Dhirajlal's the Indian Penal Code 200 (K.T. Thomas \& M.A. Rashid eds., 2014).

71 A.I.R. 1996 S.C. 1388. 
Self-preservation of one's life is the necessary concomitant of the right to life enshrined in Article 21 of the Constitution of India, fundamental in nature, sacred, previous and inviolable and such right to self-preservation has a species in the right of self-defence in criminal law. ${ }^{72}$

Countries such as Australia and Canada have already expanded their traditional self-defence structure to defend battered women who kill their abusers. ${ }^{73}$ Theoretically, self-defence appears to be most appropriate in defending battered women who kill, in the sense that, when the harm to the batterer is balanced against the abuses inflicted upon the woman, society's interest in the right of bodily integrity along with the harm caused to the violated woman outweighs the harm caused to deter such abuser.

Section 100 of the IPC uses the term "reasonably cause apprehension" which signifies that a

person who is in an imminent and reasonable danger of losing his life or limb may in exercise of self-defence inflict any harm even extending to death on his assailant either when the assault is attempted or directly threatened and such right of private defence commences as soon as a reasonable apprehension arises which is co-terminus with the duration of such apprehension. ${ }^{74}$

It is evident from the prerequisites that self-defence predominantly relies on the components of imminence, necessity and proportionality. A review of some of the cases where self-defence has been pleaded by women will give a more accurate view of the standard applied in these cases. For instance, in Malliga v. State, ${ }^{75}$ the deceased brother of the accused had physically assaulted and tried to rape her. The question before the court was whether a helpless woman at an advanced stage of pregnancy, under frequent and imminent threat of rape, is entitled to a right of private defence. The court held that an accused that had a reasonable belief or apprehension of the continuing danger to her body of being raped, as well as harm to the child in her womb was entitled to exercise the right of private defence in terms of Section 100 and 102 of the IPC. The court also held that while the accused bears the initial burden of setting up a plea of self-defence, the burden immediately shifts to the prosecution to establish that the accused had exceeded the right of private defence. In Meera v. State of Rajasthan, ${ }^{76}$ the accused assaulted her mother-

\footnotetext{
72 A.I.R. 1996 S.C. 1388.

73 Sheehy et al. 2012, at 468.

74 Ratanlal \& Dhirajlal's the Indian Penal Code, supra note 70, at 85.

75 (1997) S.C.C. OnLine Mad. 787.

76 (1998) S.C.C. OnLine Raj. 821.
} 
in-law. She pleaded that she acted in the exercise of her right of self-defence. The court held that the accused is not required to prove her right of private defence beyond a reasonable doubt. It is sufficient, if on the basis of the circumstances of a particular case, the version becomes acceptable using the test of preponderance of probabilities. As a result, the court overturned the conviction. In Champa Rani Mondal v. State of West Bengal, ${ }^{77}$ the accused woman had challenged her conviction for committing the murder of her brother-in-law. According to the facts of the case, the brother in law had tried to rape her and, for the purpose of the same, dragged her to the bed by putting a piece of cloth in her mouth. It was at that very moment when she inflicted two blows of a katari upon him as a result of which he succumbed to death. ${ }^{78}$ The court acquitted her as she had exercised her right of private defence. Similarly, in Anuj Jermi v. State ${ }^{79}$ the deceased father, exhibiting animal behaviour, attempted to rape and murder his daughter, the accused, at knife point. In order to preserve her dignity and life, the accused stabbed her father with the knife nearly three times in his stomach, killing him. The court held that the petitioner acted in the exercise of her right of private defence and therefore was entitled to the benefit provided under Section 100 of the IPC.

The foregoing analysis shows that courts have accepted self-defence pleas only when the "immediacy" requirement has been satisfied. However, battered women react differently and uniquely at each stage of the cycle of violence and the majority of them end up killing the abuser in non-confrontational situations. In such cases, it would be necessary for her to prove that, although her husband was not violent during the commission of the act, she was reasonable enough to believe that if she did not kill him, he would become abusive again, and the next time he would assault her would inevitably lead to her death..$^{80}$ The problem with traditional self-defence law is that it permits lethal force to be used in self-defence only in response to an imminent threat. For a woman who is violently abused over a long period of time, the temporary withdrawal of the batterer from blatant violence does not signify the termination of danger. ${ }^{81}$ Instead, it gives her a reason to develop a well-founded fear of future attacks based on previous experiences. However, such fear does not constitute imminent danger as understood in legal terms. Although a battered woman may reasonably fear that a violent attack is imminent, it is not considered to be so. As a result, battered women may find it difficult to sustain their self defence claims in the courts. After all, as long as the abuser is asleep

77 (2000) 10 S.C.C. 608.

78 Id. 11.

79 (2012) S.C.C. OnLine Mad. 2874.

80 Lorraine P. Eber, The Battered Wife's Dilemma: To Kill or to be Killed, 32(4) Hastings L.J. 895, 928-929 (1981).

81 Kumari 1999. 
he does not appear to pose any immediate threat, retreat seems like a viable option and the killing seems like a choice rather than necessity. ${ }^{82}$

Concerning proportionality, it is worth noting that historically, the test of selfdefence was created to allow a man to protect himself, his family and his property from an attack by another man of similar size or strength. ${ }^{83}$ For instance, in Vishwanath $v$. State of U.P., ${ }^{84}$ a husband attempted to forcibly remove his wife from her brother's house (the accused) and also assaulted her in the process. The question before the court was whether the accused had the right of private defence of the body of his sister to the extent of causing the death of her husband. The court held that the accused had not caused more harm than was necessary because his sister's husband had assaulted her with the intention of abducting her, and thus the accused would not be found guilty of any offence. In Yogendra Moraji v. State of Gujarat, ${ }^{85}$ the accused had a dispute with the deceased and his associates over payment of dues. The rude behaviour of the accused was resented by the deceased and when he signalled to stop the car of the accused, the accused fired from his revolver without aiming at any particular person. The final shot hit the deceased causing his death, and as a result, the accused was charged with murder. The accused pleaded the right of self-defence, but the court held that he had exceeded his right because such a right could only be availed against an impending danger, present and real. The court also opined that,

It is a defensive and not a punitive right and therefore the injury inflicted by the person exercising the right should be commensurate with the injury. ${ }^{86}$

Similarly, in Rizan v. State of Chhattisgarh, ${ }^{87}$ the plea of self-defence was negated because the accused, prior to inflicting injuries upon the deceased, had run to a house to fetch a weapon, and such an act bearing the stamp of a design to kill takes the case out of the purview of private defence. The court held that in order to claim a right of private defence extending to voluntarily causing death, the accused must demonstrate that there were circumstances giving rise to reasonable grounds for apprehending that either death or grievous harm would be caused to him. ${ }^{88}$

82 Katelyn E. Keegan, The True Man \& the Battered Woman: Prospects for Gender-Neutral Narratives in SelfDefense Doctrines, 65(1) Hastings L.J. 283 (2013).

83 Elizabeth M. Schneider, Equal Rights to Trial for Women: Sex Bias in the Law of Self-Defense, 15 Harv. C.R.-C.L. L. Rev. 623, 635 (1980).

${ }^{84}$ A.I.R. 1960 S.C. 67.

85 (1980) 2 S.C.C. 218.

86 Id. १13-१15.

87 (2003) 2 S.C.C. 661.

88 Id. $\uparrow 14$. 
However, the concept of proportional force, which is based on the notion of people being equal in strength and aggression, is irrational when applied to women. If such a principle of proportionality is applied to the cases of battered women, it may appear absurd in the sense that the male abuser is usually stronger than the woman and since she is familiar with his violent temper and brutal nature, she ends up using deadly force in order to put an end to the violence. Above all, the self-defence structure is governed by the "reasonable man" standard. However, if the courts apply the same standard while examining a battered woman's case in which she has killed her abuser, it would be nothing but blatantly overlooking the problems which the violated woman has had to endure. The circumstances under which a battered woman finds herself are usually perceived differently by her than they may be by others. As a result, the use of the objective standard of reasonableness in order to support a claim of self-defence raises difficulties as these cases do not fulfil the essential pre-requisites. In order to avoid such a situation, the courts must examine the situation from the viewpoint of the woman in order to understand and appreciate what she has been through and the factors which motivated her to kill her abuser. A purely objective "reasonable man" standard is also unduly harsh because it ignores the characteristics which inevitably and justifiably shape the defendants' perspective, thus holding her to a standard that she simply cannot meet. ${ }^{89}$ Owing to this reason, using the standard test of self-defence might prove to be detrimental in the case of a battered woman who has killed. Thus, one of the greatest challenges in determining self-defence claims is striking a balance between the defendant's subjective perceptions and those of the hypothetical reasonable person..$^{90}$ Nonetheless, deviating from the objective reasonableness standard, the Supreme Court in Wassan Singh v. State of Punjab ${ }^{91}$ held that

reasonable apprehension of danger must be judged from the subjective point of view of the accused and cannot be subjected to microscopic and pedantic scrutiny. ${ }^{92}$

In this case, the accused had received as many as nine injuries, two of which were to his head and one of which was an incised wound caused by a sharp weapon. The court stated that under these circumstances, if the accused fired one shot from his gun in self-defence, it could not be said that he had exceeded the right of private defence, because the nature of the assault by the complainant that left him with the injuries could be said to have caused a reasonable apprehension of danger in his mind. This decision appears to be a welcome approach to the doctrine of self-defence.

89 Elizabeth Kenny, Battered Women Who Kill: The Fight Against Patriarchy, 13(1) U.C.L. Jurisprud. Rev. 17 (2007).

$90 \quad$ Id. at 36.

91 (1996) 1 S.C.C. 458 (affirmed in Raj Singh v. State of Haryana, (2015) 6 S.C.C. 268, 277).

92 Id. $\$ 10$ (S.B. Majumdar, J., majority opinion). 
In order to accommodate the cases of battered women within the self-defence structure, the courts will have to go beyond the reasonableness standard and certain factors such as a lack of adequate social welfare, an apathetic attitude of police towards domestic violence, as well as the well-founded fear of retaliation, will also have to be taken into consideration while deliberating upon a plea of self-defence, particularly the proportionality of force used, and to understand the reason as to why a battered woman did not flee from her abuser. However, there is an inherent problem with the self-defence plea when compared to the partial defence of provocation. As a justificatory defence, self-defence has an all-or-nothing approach, resulting in either an acquittal or a murder conviction, unlike provocation, which if proven might at least reduce the sentence of the accused when compared to a sentence for murder.

\subsubsection{Insanity: Excusing a Battered Woman}

Logically, it may appear that the law in general discourages killing others in an act of self-defence when less drastic measures are available to potential victims to avoid harm. However, as previously discussed, there are more than enough reasons to treat the cases of battered women differently. In such a scenario, an alternative defence, as advanced by some scholars, would include the defence of insanity for women who are faced with circumstances under which a traditional self-defence theory is likely to be unsuccessful. After all, an insanity plea focuses solely on the subjective mental state of the defendant, unlike in cases of self-defence which require an objective inquiry into the circumstances of the killing. Indian courts follow the M'Naghten Rules, formulated in the English case R. v. M'Naghten, ${ }^{93}$ while deliberating on cases where defendants plead insanity as a defence. The M'Naghten Rules, which are the continuing measure of insanity, incorporate a classical thought that is over a century old. Although attempts at modernization have led to some modifications to the rules of criminal responsibility, the statute and significance of the M'Naghten Rules have impeded efforts at creative reconstruction. ${ }^{94}$

Section 84 , which embodies the defence of insanity, is based on the fundamental norm of criminal jurisprudence that an act does not constitute a crime unless it is done with a guilty intention. In order to constitute a crime, both the intent and the act must concur. Thus, as per this section, an insane person bears no culpability owing to the fact that he or she lacks the necessary guilty intent. The section specifically uses the term "unsoundness of mind" which may differ in degree and in kind, depending on the circumstances of the case. In Ratan Lal v. State of M.P., ${ }^{95}$ the Supreme Court settled that in order to understand what constitutes unsoundness of mind, one can safely classify a person as non compos mentis, falling into the category of (a) an idiot, (b) one rendered non compos by illness, (c) a lunatic or madman or (d) a drunkard.

\footnotetext{
93 R. v. M'Naghten, [1843] U.K.H.L. J16.

94 K.M. Sharma, Defence of Insanity in Indian Criminal Law, 7(4) J. Ind. L. Inst. 325 (1965).

95 (1970) 3 S.C.C. 533
} 
Indian courts have interpreted Section 84 to posit two mental conditions which exempt a person from responsibility for their wrongful act, namely, that the unsoundness of mind was such that it rendered him incompetent to know the nature of the act or that it prevented him from understanding the wrongfulness of the act in question. ${ }^{96}$

The courts in India, however, only deal with the question of legal insanity and not medical insanity. Even though from a medical point of view, every person is insane while committing an offence, exemption from culpability can only be confined to those cases in which insanity materially impairs the cognitive faculty of the person to the point where he is unable to distinguish between right and wrong. In order to establish the defence of insanity, the mental condition as per the conditions of this section must have existed at the time the act was committed. The defence of insanity has been mainly raised in homicide cases. For instance, in Mst. Shanti Devi v. State ${ }^{97}$ the accused had cut the neck of her child with a razor. On being charged with murder, the accused pleaded insanity. Evidence revealed that prior to the occurrence, the accused had been admitted to a mental hospital and was suffering from Maniac Depressive Psychosis. It was an acute illness, and in that state she was not able to understand what she was doing or the consequences of her actions. The court held that she was entitled to the benefit of Section 84 of the IPC. The Bombay High Court had dealt with a similar situation in Saraswati Mahadeo Jadyal v. State of Maharashtra. ${ }^{98}$ In this case, the accused had strangulated her week-old infant and abandoned the body in an isolated village. The accused had also admitted that she had strangulated her child because her husband was spending all his money on drinking and was giving her nothing for the household expenses. During the course of the investigation, it was discovered that on an earlier occasion also, the woman had killed her own child, and as a result, she had been committed to a mental hospital where she was diagnosed to be medically unsound. After taking into consideration all the legal and medical factors, the High Court held that the accused was entitled to claim the benefit of Section 84. Similarly in Sumitra Shriram v. State of Maharashtra, ${ }^{99}$ the accused mother was alleged to have committed the heinous crime of killing her two minor children by throwing them into a well, as well as attempting to kill her third child and end her own life by carrying the child in her arms and jumping into the well. During the course of the investigation, it was found that the accused was suffering from an illness, and the offence she committed was a consequence of her unsound state of mind. The High Court held that, since the conduct of the accused clearly indicated that she did not have the requisite mens rea to commit the offence, her case would fall within the purview of Section 84. From the foregoing analysis of the cases, it is clear that every accused who pleaded the defence suffered from

\footnotetext{
96 Sharma 1965, at 332.

97 (1967) S.C.C. OnLine Del. 56.

981993 Mh.L.J. 1529.

$99 \quad 2000$ (2) Mh.L.J. 149.
} 
a specific "illness" for both medical and legal purposes. The question that may arise here is whether a battered woman who kills her abuser suffers from any specific illness. The answer lies in the discussion that follows.

In Dayabhai Chhaganbhai Thakkarv. State of Gujarat, the law on the burden of proof in insanity cases was well established. ${ }^{100}$ The Supreme Court began by highlighting the fundamental principle governing the law of insanity, according to which:

The burden of proof lies on the prosecution to prove beyond reasonable doubt that the defendant caused the death with the requisite intention described in Section 299 of the Indian Penal Code. However, Section 84 being an exception, it has to be read with Section 105 of the Evidence Act, 1872 whereby the burden of proving the existence of circumstances bringing the case within the said exception lies on the defendant. ${ }^{101}$

The Supreme Court appears to have broadened the scope of the defence by stating that:

Even if the evidence placed by the defendant does not discharge the burden under Section 105 sufficiently, if it is able to raise a reasonable doubt in the mind of the judge, the defendant has to be acquitted on the ground that the prosecution has failed to conclusively prove the guilt of the defendant. ${ }^{102}$

As a result, the law places the burden on the prosecution to prove both actus reus and mens rea beyond a reasonable doubt. The same was affirmed by the Supreme Court in Bhikari v. State of Uttar Pradesh ${ }^{103}$ which held that the burden of proving the intention of the accused person, where intention is an ingredient of the offence, is on the prosecution and this burden never shifts..$^{104}$ Subsequently, in Oyami Ayatu v. State of M.P., ${ }^{105}$ the Supreme Court observed that,

Section 84 could be invoked by a person to nullify the evidence adduced by the prosecution by establishing that he was at the relevant time incapable of knowing the nature of the act or that what he was doing was contrary to law..$^{106}$

\footnotetext{
100 A.I.R. 1964 S.C. 1563. 
The Supreme Court, very recently, clarified the law on this issue by stating that

though the burden of proof is on the accused as per Section 105, he is not required to prove the same beyond all reasonable doubt but merely satisfy the preponderance of probabilities. ${ }^{107}$

In such a scenario, the defence of insanity can well be pleaded by battered women as they only have to nullify the contention of the prosecution by adducing evidence that she was not in a proper mental condition to understand the consequences of her actions.

Theoretically, the image of a battered woman as portrayed by Walker would clearly fall within the scope of Section 84. A battering relationship can and does have a devastating psychological effect on the violated woman which is even more severe and damaging than the physical abuse itself. The "cycle of violence" theory and the "learned helplessness" concept as put forth by Walker evidently illustrate the consequences of the violated woman's continuous failure to repair or step out of the violent relationship. The result of the cyclical highs and lows inherent in the violent relationship is that the woman's judgement becomes severely impaired. Thus, what follows from such an analogy is that at the time of homicide, the battered woman suffered from an impaired mental state as a result of her repeated beatings and the pre-emptive force used by her was according to her state of mind, necessary to avert an otherwise unavoidable threat by the abuser. The nexus between a woman's impaired judgement and the homicide can be established by proving that the woman viewed her unyielding circumstances from a psychologically distorted perspective, thus rendering it highly unlikely that she could have found any possible alternatives to killing. With respect to the required degree of cognitive dysfunction, she is similar to a person of unsound mind as described under the M'Naghten Rules owing to the fact that she is honestly incapable of understanding that her act was either morally or legally wrong. In such a scenario, it would be easy for a battered woman killing her abuser to prove that she lacked mens rea by adducing evidence in order to prove her mental condition at the time when she committed the act. In order to bring the case of a battered woman under Section 84, adducing expert evidence on BWS would be extremely relevant in determining the circumstances in which the battered woman killed her abuser, thereby allowing her to relevantly include all events in order to explain her state of mind. In light of the same, it would be pertinent to analyse Manju Lakra, where the High Court itself opined that, as per the circumstances faced by the battered woman, the intention of the woman was not to kill her husband but to put an end to the continuing violent acts and as a consequence thereof, she felt that nothing short of putting an end to the life of her husband would be a solution. Even though the battered woman relied upon the partial defence of provocation, it is believed

107 Surendra Mishra v. State of Jharkhand, (2011) 11 S.C.C. 495, १13 (C.K. Prasad, J., majority opinion). 
that the plea of insanity could have easily been resorted to in order to prove that the battered woman while committing the act was not in a state of mind to understand that her act was legally wrong, since she was acting in self-preservation. Since it is an obligation on the part of the prosecution to prove guilt beyond a reasonable doubt, it would have been extremely difficult for them to prove that the actus reus concurred with the mens rea, since the guilty intent itself was lacking in this case.

Despite the benefits that the defence of insanity has to offer, it has certain inherent limitations attached to it. A major difficulty with the use of this defence is that, instead of providing vindication to the violated woman, it coerces the woman to effectively accept an identification of a psychologically impaired person. It basically reflects the male-centric approach of the legal system whereby men are painted as victims of unreasonable circumstances and women as violators. The invidiousness of this predicament is explained by Sanghvi and Nicolson to mean that unless these women accept a label of psychological abnormality, they run the risk of escaping the prison of domestic violence only to spend a long time in a less metaphorical prison. ${ }^{108}$ Another factor that weighs against a plea of insanity is the possibility of an outcome of incarceration in institutions by reason of unsoundness of mind, instead of an acquittal. Furthermore, even after acquittal, the woman might have to face the stigma of being categorised as "insane." This is one of the major reasons why many feminist advocates advise that the defence of insanity should be used "only as a last resort" with full awareness of its social implications. ${ }^{109}$ Does a woman, who has suffered in an abusive relationship, deserve such an end? This question has remained unanswered for so long that when a battered woman is found to be "insane," the State merely takes a reactive response rather than making any effort to tackle the real, substantial problem of domestic violence. It is totally unjustified to castigate a battered woman as an "abnormal" scapegoat for taking the law, which failed her, into her own hands to ensure survival.

\section{Limitations of Battered Woman Syndrome and the Need for a New Defence}

From the analysis in the previous section, it is quite evident that the existing criminal law in India fails to provide a defence which can be consistently implemented to fully justify or excuse a battered woman who killed her abuser in order to put an end to the cycle of violence. The defences discussed are either too severe to apply effectively with any uniformity or have adverse results if applied successfully. Owing to the fact that domestic violence is prevalent within homes, it becomes pertinent to

108 Rohit Sanghvi \& Donald Nicolson, Battered Women and Provocation: The Implications of R v Ahluwalia, Crim. L. Rev. 728 (1993).

109 Elizabeth M. Schneider \& Susan B. Jordan, Representation of Women Who Defend Themselves in Response to Physical or Sexual Assault, 4(3) Women's Rts. L. Rep. 149, 160 (1978). 
consider defining a different approach under which battered women can successfully assert a defence and be acquitted with some degree of reliability. The previous analysis also portrays the latent gender bias operating in the very conceptualisation, formulation and operation of the defences. In order to address this very concern, BWS had gained momentum in the judicial process of various countries, as discussed earlier, which eventually led to criminal law reform to accommodate the cases of battered women. Since India has yet to see such a reform, it will be pertinent to analyse whether incorporating BWS within the framework of criminal law can aid in including the perspectives, interests and experiences of women while deliberating upon these cases of battered women.

\subsection{Battered Woman Syndrome: A Convenient Label or Real Syndrome?}

There is no doubt that the establishment of BWS has actually exposed the problem of abuse against women. However, introducing BWS as a defence under criminal law in India could be harmful rather than helpful for women who kill their abusers in order to end the cycle of violence. The discussion in the previous section gives a clear picture of the Indian legal system's lack of familiarity with the concept of BWS, so much so that in none of the cases have the advocates defending battered women sought to adduce expert evidence on BWS. The present study shows that introducing BWS as a stand-alone defence will certainly have adverse effects on women who do not fit into the image of battered women, as portrayed by Lenore Walker. ${ }^{110}$ The inherent limitation of BWS is the notion of psychological disorder associated with it which portrays a stereotype and makes a battered woman an "irrational being." Do we really need to label a woman as "irrational" in order to justify her act of self-preservation? Instead of emphasising her conduct as being rational, reasonable and comprehensible, BWS attaches a stigma of mental disorder. Apart from that, introducing BWS as a defence might perpetuate a picture of domestic violence as a rare occurrence rather than a common happening which takes place every minute inside the four walls of a household. BWS as a defence might negate the very purpose behind incorporating it, as it in no way addresses the inherent genderbias of the criminal law and by categorising the woman as "psychologically unstable," it might actually reinforce the existing bias. In such a scenario, it is actually more convenient that India has not yet introduced BWS as a defence to accommodate the cases of battered women. Another point which can be raised is that, if we consider that BWS comprises mental symptoms, why should there be a separate defence when the battered woman can simply rely on an insanity plea? This question has already been answered in the previous chapter as to the repercussions of using the defence of insanity. Using BWS as a defence may help defend the case of a battered woman, but there is a high chance that the woman is likely to be institutionalised

110 Leigh Goodmark, When Is a Battered Woman Not a Battered Woman? When She Fights Back, 20(1) Yale J.L. \& Feminism 75 (2008). 
owing to the notion of psychological disorder associated with her. As a result, such women may be perceived as suffering from a permanent mental condition that renders them incapable of caring for and protecting their children, dangerous to their dependants, unreliable and beyond hope of rehabilitation.

On the feasibility of introducing BWS evidence in order to address the concerns of battered women, it can be said that adducing expert testimony of BWS actually reinforces the notion of women lacking credibility as witnesses. The woman is supplanted by an expert whereby, "she is only a cog in the machinery, neither believed nor trusted."'"1 Moreover, BWS testimony would underline the stereotypes attached to the concept of wifehood. The main reason is that the term does not counteract prejudicial stereotypes of battered women and promote an unbiased assessment of their circumstances, including their fear of harm, their inability to escape, the unresponsiveness of legal authorities and a lack of other alternatives. ${ }^{112}$ Instead, it might perpetuate the existing stereotypes and explain what is wrong with such women psychologically. ${ }^{113}$ Do we really need a "syndrome" to explain the actions of a battered woman? On the face of it, the syndrome might help in obtaining acquittals, but it may have adverse effects in the future. It might end up penalising those women who do not fit the said psychological profile because it fails to focus on the real issue, namely, the lack of alternatives for battered women, and serves to obscure the fact that existing legal standards of reasonableness do not incorporate these women's experiences. Moreover, the stereotypes embedded in BWS might raise the issue of courts remaining uncertain about how to utilise such expert evidence and that too in the correct way. Limiting expert testimony only to BWS in cases of battered women will result in focussing only on the mental condition of the woman rather than recognising the violent acts committed by her abusive partner. Furthermore, expert evidence on BWS does not confront the narrow, male standard upon which reasonableness is constructed. Although the use of BWS in the judicial process arose in response to issues with the interpretation of male standards, the narrow reasonable standard remains unperturbed, with expert evidence being necessary to explain the departure of the action of a battered woman from that standard..$^{114}$ Those who argue in favour of using BWS emphasise the importance of the judges' understanding of the experience such a woman is likely to have endured as a result of the violence. It follows then that BWS can only play a very educative role rather than supporting the defence claims of battered women. This argument can further be justified by the use of the courts to explain the effects of a battering relationship in cases other

111 Alafair S. Burke, Rational Actors, Self-Defense and Duress: Making Sense, Not Syndromes out of the Battered Woman, 81(1) N.C. L. Rev. 211, 221 (2002).

112 David L. Faigman, The Battered Woman Syndrome and Self-Defense: A Legal and Empirical Dissent, 72(3) Va. L. Rev. 619 (1986).

113 Sheehy et al. 2012, at 470 .

114 Id. 
than those of homicides committed by battered women. ${ }^{115}$ The introduction of BWS testimony may be generally educational for judges and advocates in understanding the effects of abuse in domestic violence, but using it in order to support a defence would obviously undermine a woman's claim to have acted reasonably.

\subsection{The Path Ahead: Need for a Complete Defence}

Since introducing BWS as a defence or adducing expert testimony on BWS to support a defence plea does not appear to be a viable option, there is indeed a need to formulate a specific defence which will accommodate the cases of battered women. Even though the number of women committing homicides as a result of a battering relationship in India is small, it would be deeply wrong to punish a woman for failure on the part of the State to provide adequate protection to her. In such a scenario, a new complete defence can be framed to address the plight of battered women who kill their abusers. Such a defence must be justificatory in nature, which would result in the acquittal of a battered woman. Furthermore, the provision should be worded in such a manner so that it is clear that it is primarily constructed for women in abusive relationships but that it is also available to men. Such a standard has to be maintained while framing a complete defence so that formal gender neutrality does not obliterate the reality of the victims of domestic violence. To that end, a broad outline for the inclusion of a new defence under Chapter IV of the IPC can be proposed as follows:

\section{Act done in furtherance of abuse in a domestic relationship:}

Nothing is an offence by reason that it causes death of the assailant if such an act is done under a reasonable apprehension of danger arising out of violence in a domestic relationship.

Explanation 1 - An apprehension of danger may be reasonable even if the acts of violence are recurrent in nature.

Explanation 2 - The alleged act must be proportional to the apprehended danger in view of the person committing such act.

Explanation 3 - For the purpose of this section, "domestic relationship" shall have the same meaning as under Section 2(f) of Protection of Women from Domestic Violence Act, 2005.

Inclusion of a complete defence in line with the proposed provision will take into consideration the state of the battered woman involved in a turbulent relationship not by pathologising her but treating her as a victim of abuse. The foregoing proposition also does away with the inherent objectivity in the existing defences, as it proposes to judge the danger from the subjective point of view of the person committing the act. However, the defence can only be fully effective if the reasonable

115 See State v. Hari Prashad, (2016) 228 D.L.T. 1 (D.B.); Amutha v. State, 2014 (2) M.W.N. (Cr.) 605. 
man standard is substituted by a gender-neutral standard which would allow such women to receive fair treatment in courts. A battered woman is obviously not a reasonably prudent person because her circumstances completely differ from that of a person who has not faced such violence. She is an expert on her situation and is better equipped than anyone else to assess when danger is looming. A battered woman has an in-depth knowledge of the actions of her abuser that a woman who has not faced these experiences does not have. Therefore, considering her actions only in the light of a reasonable man, when through no fault of her own she does not qualify as one, is in essence, condemning her for her suffering. ${ }^{116}$

However, in order to effectively use this uniform defence, preventing any sort of misuse, the battered woman would have to fulfil two requirements. Firstly, the woman would have to prove the circumstances faced by her in the abusive relationship and as to why she eventually killed. Such a burden may be discharged with the help of expert testimony. However, instead of adducing evidence on BWS, a broad range of expert testimony under Section 45 of the Indian Evidence Act, 1872 should be allowed by the court to prove the effects of the battering relationship. Such evidence should include evidence of physical, sexual and psychological abuse, including deprivation of financial resources and social isolation, and also include the history of violence. The evidence must be used to discharge the burden imposed upon the battered women under Section 105 of the Indian Evidence Act, 1872. After having discharged such a burden, the advocate defending the battered woman by invoking the gender neutral standard would attempt to prove that under the defendant's circumstances, she acted as a reasonable battered woman would have acted and thus was justified in killing her batterer. The court should take into account all of the existing evidence regarding the defendant's history with the victim and should deliberate upon the issue by viewing the battered woman as having been cumulatively affected by these factors. This would ensure a fair determination of the woman's innocence or guilt. Apart from ensuring fairness, this new defence would serve as a deterrent to men who inflict violence upon their significant other. Seeing that women have recourse to the law, the abusive partner will be deterred from inflicting abuse and the menace of domestic violence would be mitigated to a certain extent.

No law or legal provision can be successful until and unless people are made aware of the consequences of such a provision. In order to deal with the cases of women who commit homicide in these extreme kinds of situations, primarily the judges and the advocates should be sensitised about the persistent domestic violence within families. Even though an argument has been made in this study for the inclusion of a complete defence, efforts should be made so that women would hardly need to confront such a situation where they would have to kill their husbands to put an end to such an abusive relationship. This can only be achieved by changing

116 Steffani J. Saitow, Battered Woman Syndrome: Does the Reasonable Battered Woman Exist?, 19(2) New Eng. J. on Crim. \& Civ. Confinement 329, 340 (1993). 
the societal attitude towards domestic violence as a serious crime. This demands not only proper implementation of the existing laws on domestic violence by the law enforcement agencies but also committed political pledges by the government to protect women from violence. It is believed that the inclusion of this defence might provide the requisite impetus to challenge the down-grading of domestic violence to the private arena by compelling the legal institutions to treat domestic violence as a serious public issue, which would ultimately reduce the chances of such homicides being committed by women in self-preservation.

\section{Conclusion}

The present study began with a quest to examine whether incorporating Battered Woman Syndrome within the framework of criminal law in India will address the concerns of battered women by ungendering the existing criminal law which is resistant towards women's accounts of experiences. The specific question regarding the inclusion of BWS as a defence has been answered in the negative on the ground that the concept, which stereotypes a woman as irrational, reinforces the existing gender bias, thereby leaving the narrow male standards unperturbed. As it is quite evident from this study, the way in which BWS has been resorted to by Indian courts clearly portrays the educative value possessed by the theory to explain the effects of being in an abusive relationship. But to include BWS either as a defence or by way of expert evidence would be more harmful than helpful, considering the inherent limitations attached to the theory itself. BWS unreasonably stereotypes a battered woman who might actually be acting rationally given her prevailing social and living conditions, and by reinforcing the apparent irrationality of her behaviour, it might actually reinforce incapacity and inferiority in women who invoke such a defence.

Given the potential negative consequences of using BWS, it clearly does not seem to be a viable option to incorporate it within our criminal law framework. There might be a chance that if the theory of BWS itself is redefined by eliminating the notion of a "syndrome" and learned helplessness, these negative consequences could be avoided. Furthermore, the need to protect women who have suffered tremendous physical and psychological abuse in their domestic relationships cannot be ignored. The proposal to include a justificatory defence is made by the author on the ground that many battered women are faced with no realistic alternative to the use of lethal force against their abusive partners. It is the law itself that legitimises male violence against women by failing to provide adequate protection to them and their dependent children. In such a scenario, it is not at all reasonable to attach any sort of culpability to a woman who merely acts in order to save her own life or that of her children. However, the inclusion of such a defence does not mean authorising a woman's right to kill. It is just a precautionary measure whereby abusive partners will also be deterred from knowing that women now have recourse to a legal defence. 
It is not possible at this juncture to predict the fate of the proposal made owing to the fact that the number of reported cases on this subject is very few. However, it is quite certain that there is a dire need to ungender criminal law in India to recognise circumstances unique to women. Introducing a defence itself will never solve the problem, unless the social conditions which breed, facilitate and maintain violence within the four walls of a household are changed. The first step towards such a change could be to strengthen girls and women so that they are more resistant to abusive behaviour, and also to change the attitudes of men who treat women like property and mere objects of sex. Defences will also not be effectively used in courts unless the stakeholders are educated about the effects of battering relationships as they will eventually be subjected to the ingrained cultural judgement of the judges and, at least to some extent, the blame for such occurrences in the relationship will be attached to her. Instead of limiting the scope of expert testimony to BWS, the help of domestic violence experts can be taken while deliberating upon the cases of battered women to understand the effects of the abusive relationship on the mind and body of the abused woman by not labelling her as an "abnormal" or "irrational" woman, but by treating her as a victim of long-lasting domestic violence. Sensitisation about the effects of being in a battering relationship should not be limited only to the judges but must extend to all the stakeholders, e.g. advocates, police officers, counsellors, and such, associated with the justice delivery system so that they can reframe their own mindset and face reality. Apart from that, the common people also should be educated about the abuse faced by women at the hands of their own partners, so that they can recognise and report such abuse and also remain sensitive to the abused instead of blaming the abused unfairly.

The author has argued for the inclusion of women's experiences into the existing criminal law that will challenge the legal fiction of neutrality and universality. Perhaps, the primary purpose that this study tries to serve is to make lawmakers aware of the fact that there exists a group of women, even though very few, who are badgered and battered by their respective partners, and when they face a do-or-die situation, they end up killing their abusers. The law, which aspires to represent both men and women equally, is in fact "male" and thereby fails to accommodate the circumstances of these women. If the law is to be truly gender-neutral and universal in its approach, it will have to change its practice. Such a change can only be brought about when lawmakers have the knowledge of, and acknowledge the difference between, the circumstances of men and women.

\section{References}

Borthakur A.D. The Case for Inclusion of Battered Woman Defence in Indian Law, 11(1) NUJS L. Rev. 1 (2018).

Clough A. Battered Women: Loss of Control and Lost Opportunities, 3(2) J. Int'I \& Comp. L. 279 (2016). 
Edwards S.S.M. Anger and Fear as Justifiable Preludes for Loss of Self-Control, 74(3) J. Crim. L. 223 (2010). https://doi.org/10.1350/jcla.2010.74.3.638

Goodmark L. When Is a Battered Woman Not a Battered Woman? When She Fights Back, 20(1) Yale J.L. \& Feminism 75 (2008).

Gruber A. A Provocative Defense, 103(2) Calif. L. Rev. 273 (2015).

Gupta S. Right to Kill: The Case of the Battered Women, 3(2) Nirma Univ. L.J 59 (2014). Jaising I. Domestic Violence and the Law, 1 J. Nat'I Hum. Rts. Comm'n 72 (2002).

Kenny E. Battered Women Who Kill: The Fight Against Patriarchy, 13(1) U.C.L. Jurisprud. Rev. 17 (2007).

McColgan A. In Defence of Battered Women Who Kill, 13(4) Oxf. J. L. Stud. 508 (1993). https://doi.org/10.1093/ojls/13.4.508

Norrie A. The Coroner's and Justice Act 2009 - Partial Defences to Murder (1) Loss of Control, 4 Crim. L. Rev. 275 (2010).

Saitow S.J. Battered Woman Syndrome: Does the Reasonable Battered Woman Exist?, 19(2) New Eng. J. on Crim. \& Civ. Confinement 329 (1993).

Schneider E.M. Equal Rights to Trial for Women: Sex Bias in the Law of Self-Defense, 15(5) Harv. C.R.-C.L. L. Rev. 623 (1980).

Sharma K.M. Defence of Insanity in Indian Criminal Law, 7(4) J. Ind. L. Inst. 325 (1965). https://doi.org/10.1037/e452852008-342

Sheehy E. et al. Defences to Homicide for Battered Women: A Comparative Analysis of Laws in Australia, Canada and New Zealand, 34(3) Sydney L. Rev. 467 (2012).

Walker L.E. The Battered Woman Syndrome (4 ${ }^{\text {th }}$ ed., Springer, 2016). https://doi. org/10.1891/9780826170996

Wells C. Battered Woman Syndrome and Defences to Homicide: Where Now?, 14(2) Leg. Stud. 266 (1994). https://doi.org/10.1111/j.1748-121x.1994.tb00502.x

\section{Information about the author}

Aishwarya Deb (Kolkata, India) - Doctoral Candidate, West Bengal National University of Juridical Sciences (12 LB Block, Sector III, Bidhannagar, Kolkata, West Bengal, 700098, India; e-mail: aishwarya.deb@nalsar.ac.in). 